\begin{tabular}{|l|l|l|l|l|l|}
\hline J. Tek. Ling & Vol. 13 & No. 2 & Hal. $193-201$ & Jakarta, Mei 2012 & ISSN 1441-318X \\
\hline
\end{tabular}

\title{
POTENSI SAMPAH KOTA SEBAGAI BAHAN BAKU KOMPOS UNTUK MENDUKUNG KEBUTUHAN PUPUK ORGANIK DALAM RANGKA MEMPERKUAT KEMANDIRIAN PANGAN
}

\author{
Firman L. Sahwan \\ Peneliti di Pusat Teknologi Lingkungan \\ Badan Pengkajian dan Penerapan Teknologi
}

\begin{abstract}
Abstrak
Penurunan kualitas dan produktivitas sumberdaya lahan pertanian terutama disebabkan oleh kandungan C-organik yang rendah dan pemupukan yang tidak diimbangi dengan pupuk organik. Cara mengatasinya adalah mengembalikan bahan organik ke lahan pertanian melalui penggunaan pupuk kompos atau pupuk organik granul (POG) berbahan baku kompos. Pupuk kompos sebaiknya dibuat dari seluruh potensi bahan organik yang ada. Timbulan sampah kota yang besar dengan prosentase bahan organik yang tinggi, memiliki karakteristik yang cocok untuk dijadikan pupuk kompos berkualitas baik, dalam rangka memenuhi kebutuhan pupuk organik. Pupuk kompos memiliki kemampuan untuk memperbaiki dan meningkatkan sifat fisik, biologi dan kimia tanah. Keberhasilan program penggunaan pupuk kompos atau pupuk organik yang lain sangat bergantung kepada dukungan stakeholders terkait, serta kepercayaan petani untuk menggunakan pupuk organik. Dengan ketersedian pupuk organik yang berkualitas, yang diberikan secara berimbang bersama pupuk kimia, maka kualitas dan produksivitas sumberdaya lahan pertanian dapat ditingkatkan sehingga dapat mendukung dan memperkuat kemandirian pangan.
\end{abstract}

Kata Kunci: Sumberdaya lahan pertanian, pupuk organik, sampah kota, kompos, kemandirian pangan.

\begin{abstract}
The quality and productivity degrade of agricultural land resources mainly due to the low level of C-organic content and the fertilizing that do not use organic fertilizers. The way to solve it is by restoring the organic matter to agricultural land through the use of compost or organic fertilizer granules made from compost. Compost should be made from all organic materials that have potential. The high level of municipal solid waste generation with a high percentage of organic matter, contain the characteristics that are suitable to made a good quality compost, in order to meet the needs of organic fertilizer. Compost has the ability to improve and enhance the physical, biological and chemical soil properties. The successful of compost or other organic fertilizer utilization program is mainly depend on the stakeholders support, as well as the confidence of farmers to use organic fertilizer. With the availability of good quality of organic fertilizer, which is given in a balanced way with chemical fertilizers, the quality and productivity of agricultural land resources can be improved to support and strengthen the food self-sufficiency.
\end{abstract}

Key words: Agricultural land resource, organic fertilizer, municipal solid waste, compost, food self sufficiency. 


\section{PENDAHULUAN}

\subsection{Latar Belakang}

Terasa aneh kalau negara agraris seperti Indonesia mengimpor kebutuhan pangannya. Untuk itulah sejak tahun enam puluhan program pertanian intensif dan modern gencar dilaksanakan seperti penggunaan varietas unggul, pupuk kimia, pestisida kimia, pengairan serta penggunaan mesin pertanian untuk mengolah tanah dan proses pasca panen. Hasilnya cukup nyata, yaitu dengan tercatatnya sejarah keberhasilan negara Indonesia berswasembada pangan. Saat itu kita bisa mencukupi kebutuhan pangannya sendiri, dan lepas dari sebutan sebagai pengimpor beras.

Namun dibalik keberhasilan tersebut, dampak negatif terhadap sumberdaya lahan juga terasa, terutama yang diakibatkan oleh penggunaan pupuk kimia. Sumberdaya lahan yang telah dipacu seolah kelelahan, sehingga produktivitas tanaman pangan menurun dan predikat swasembada pangan sulit dipertahankan.

Dalam rangka memperkuat kemandirian pangan, pemerintah telah menetapkan swasembada produksi sebagai salah satu indikator keberhasilan pembangunan pertanian baik dalam rangka pelestarian (padi dan jagung) maupun pencapaian swasembada produksi komoditas baru (kedelai, gula, dan daging sapi) ${ }^{1}$. Keberhasilan kebijakan tersebut sangatlah bergantung kepada kondisi sumberdaya lahan pertanian yang ada, selain faktor-faktor pendukung yang lain.

Pada kenyataannya, sumberdaya lahan pertanian saat ini sedang mengalami penurunan kualitas dan produktivitas, yang umumnya disebabkan oleh:

- Pemahaman yang kurang memadai tentang fungsi bahan organik ${ }^{2}$.

- Bagian-bagian tanaman yang tidak dimanfaatkan pada saat panen tidak dikembalikan lagi ke dalam $\operatorname{tanah}^{2 \mathrm{dan} 3)}$.

- Penggunaan pupuk kimia dengan dosis tinggi dan terus menerus dalam jangka waktu lama serta tidak diimbangi dengan penggunaan pupuk organik (pupuk kandang, pupuk hijau, dan kompos) ${ }^{4}$.

- Intensitas pertanaman yang tinggi dengan pengelolaan yang salah telah mengakibatkan pengurasan unsur hara tanah, sehingga terjadi defisit hara ${ }^{3)}$.

- Tingkat pelapukan dan pencucian intensif sebagai akibat curah hujan dan suhu yang tinggi ${ }^{3}$.

Permasalahan di atas umumnya berkaitan dengan bahan organik (C-organik) tanah. Tanah umumnya mengandung $2-10 \%$ bahan organik yang merupakan seluruh senyawa karbon di dalam tanah. Walaupun persentasenya sedikit, namun peranannya sangat penting terhadap kesuburan tanah dan nutrisi tanaman ${ }^{5}$, sehingga bahan organik disebut sebagai nyawanya tanah²). Kondisi kandungan C-organik tanah saat ini $73 \%$ tergolong rendah $(<2 \%), 23 \%$ tergolong sedang $(2-3 \%)$ dan hanya $4 \%$ yang tergolong tinggi $(>3 \%)^{3)}$. Secara lebih spesifik, Badan Litbang Pertanian menyatakan bahwa $65 \%$ dari 7,9 juta hektar lahan sawah di Indonesia memiliki kandungan bahan organik rendah sampai sangat rendah (C-organik $<2 \%)^{4}$.

Mengingat peran bahan organik yang sangat penting pada satu sisi dan adanya permasalahan bahan organik tanah pada sisi yang lain, maka penggunaan pupuk organik untuk memperbaiki kualitas dan produktivitas lahan pertanian, merupakan suatu keharusan. Kebijakan penggunaan pupuk organik harus dapat memanfaatkan seluruh potensi bahan baku yang ada, termasuk penggunaan sampah kota. Sejalan dengan kebijakan tersebut, terdapat faktor-faktor yang mendorong peningkatan penggunaan pupuk organik yaitu: meningkatnya pemahaman yang benar mengenai fungsi pupuk organik; meningkatnya pencemaran lingkungan (tanah, udara, dan air) akibat penggunaan agrochemical yang berlebihan; makin 
mahal dan makin sukarnya memperoleh bahan baku pupuk buatan; meningkatnya permintaan terhadap produk pertanian organik; dan bahan baku pupuk organik yang banyak tersedia secara lokal dan terbarukan ${ }^{2)}$, serta kebijakan Go Organik 20106).

\subsection{Peranan Pupuk Kompos}

Degradasi sumberdaya lahan pertanian yang terjadi, umumnya berkaitan dengan rendahnya kandungan bahan organik dan pemupukan yang tidak diimbangi dengan penggunaan pupuk organik. Dengan demikian, upaya untuk mengatasinya adalah dengan menambahkan bahan organik ke dalam tanah melalui pemupukan pupuk organik, yang salah satunya adalah kompos, baik dalam bentuk curah (tepung), bentuk granul maupun dalam bentuk yang lainnya. Kehandalan pupuk organik kompos adalah karena sifatnya yang dapat memperbaiki sifat fisik, biologi dan kimia tanah, secara sekaligus. Karena sifatnya yang demikian, maka pupuk organik kompos disebut dengan soil conditioner.

Sifat fisik tanah yang diperbaiki adalah struktur dan tekstur tanah melalui pembentukan agregat yang lebih stabil, gembur serta aerasi dan drainase tanah yang baik. Tanah berpasir menjadi lebih kompak dan tanah liat menjadi lebih gembur, sehingga memudahkan pengolahan tanah. Penyerapan sinar matahari menjadi lebih banyak karena pengaruh warna gelap dari kompos. Selain itu, kemampuan menahan air meningkat sehingga terjadi efisiensi penggunaan sumberdaya air.

Perbaikan sifat biologi tanah terjadi karena pupuk organik kompos akan meningkatkan populasi dan keragaman biota tanah, terutama yang berpengaruh positif terhadap kondisi tanah. Aktivitas dan metabolisme dari biota tanah (mikroba, meso dan makrobiota) akan meningkatkan produktivitas tanah dan tanaman, melalui: peningkatan ketersediaan hara tanah, seperti pengambilan $\mathrm{N}$ dari udara dan pelarutan $\mathrm{P}$ yang tadinya tidak tersedia, terbentuknya zat yang dapat memacu pertumbuhan tanaman, terbentuknya zat yang dapat menekan pertumbuhan mikroorganisme penyebab penyakit tanaman, selain dapat mengurangi unsur toksik (anti toksik) bagi tanaman maupun bagi biota tanah.

Sedangkan sifat kimia tanah menjadi lebih baik karena adanya unsur hara esensial yang lengkap, baik makro maupun mikro, pengambilan unsur hara dari pemupukan pupuk kimia yang semakin efisien, perbaikan $\mathrm{pH}$ tanah serta kapasitas tukar kation dan kapasitas sanggah tanah (buffer capacity) yang meningkat.

Dengan sifat dan kemampuan yang dimiliki oleh pupuk kompos tersebut, maka penggunaannya secara tepat dan seimbang akan dapat meningkatkan kualitas dan produktivitas sumberdaya lahan pertanian.

\section{TEKNOLOGIPROSES KOMPOSTING DAN KARAKTERISTIK SAMPAH KOTA}

Kompos merupakan materi organik sederhana yang relatif stabil menyerupai humus sebagai hasil dari penguraian (dekomposisi) materi organik yang kompleks oleh konsorsium mikroorganisme dalam kondisi aerob dan termofilik yang terkendali 7,8,9 dan 10). Sedangkan difinisi pupuk organik menurut Peraturan Menteri Pertanian, Nomor 70/Permentan/SR.140/10/2011 adalah pupuk yang berasal dari tumbuhan mati, kotoran hewan dan/atau bagian hewan dan/atau limbah organik lainnya yang telah melalui proses rekayasa, berbentuk padat atau cair, dapat diperkaya dengan bahan mineral dan/atau mikroba, yang bermanfaat untuk meningkatkan kandungan hara dan bahan organik tanah, serta memperbaiki sifat fisik, kimia dan biologi tanah ${ }^{11}$. Dengan difinisi tersebut, maka pupuk kompos merupakan salah satu pupuk organik yang sengaja dibuat melalui suatu proses yang terkendali yang disebut pengomposan, 
untuk menghasilkan pupuk organik yang berkualitas.

Teknologi pembuatan pupuk kompos sudah begitu berkembang, mulai dari teknologi yang sederhana sampai yang canggih, mulai dari sistem terbuka hingga sistem tertutup di dalam reaktor dengan menggunakan injeksi udara. Reaktor yang digunakan beragam, seperti reaktor menara tegak, horizontal dan miring. Namun dari semua teknologi tersebut, prinsip dasarnya sama. Teknologi komposting yang paling sesuai untuk kondisi Indonesia, berdasarkan kondisi iklim, ekonomi dan sosial budaya adalah sistem dengan tumpukan terbuka (open windrow) atau modifikasinya ${ }^{10}$.

Teknologi open windrow merupakan sistem atau cara pembuatan kompos dengan cara menumpuk memanjang dari materi organik yang akan dikomposkan. Secara periodik dilakukan pembalikan, sedangkan proses penyiraman dalam rangka menciptakan kadar air yang optimal dilakukan sesuai kebutuhan. Proses komposting tersebut sebaiknya dilakukan di plant komposting, yang merupakan bangunan beratap dengan dinding terbuka. Sedangkan lantainya sebaiknya disemen (difloor). Teknologi open windrow merupakan sistem yang sederhana, namun tetap mengacu pada ilmu komposting modern, sehingga kompos yang dihasilkan berkualitas baik. Sistem tersebut juga sangat fleksibel, sehingga mudah untuk dijadikan acuan ataupun diaplikasikan di masyarakat, serta mudah disesuaikan dengan situasi dan kondisi perkotaan di Indonesia.

Parameter utama yang berpengaruh terhadap berlangsungnya proses komposting yang baik adalah rasio $\mathrm{C} / \mathrm{N}$, kadar air, konsentrasi oksigen, ukuran partikel, suhu, $\mathrm{pH}$ dan ketersediaan konsorsium mikroorganisme ${ }^{7,8,9,10)}$. Faktor-faktor tersebut perlu dibahas satu persatu dikaitkan dengan sifat dan karakteristik sampah kota.

Perbandingan karbon dan nitrogen (rasio $\mathrm{C} / \mathrm{N}$ ) ideal untuk suatu proses komposting adalah antara 20 sampai 40 atau optimalnya 30 karbon berbanding dengan 1 (satu) nitrogen. Sampah kota memiliki rasio C/N 30-40 berbanding 1(satu), sehingga cukup optimal untuk suatu proses komposting. Begitu pula kadar air sampah kota yang berkisar antara 44,81-56,58\% untuk sampah pemukiman dan pasar di DKI Jakarta ${ }^{12)}$ akan mendukung kebutuhan kadar air optimal proses komposting yang 50-60 \%. Apabila dalam proses komposting dirasakan kekurangan kadar air, maka dapat dilakukan penyiraman agar kondisi kadar air optimal selalu dapat dipertahankan.

Proses pengomposan merupakan proses aerob. Paling sedikit $50 \%$ konsentrasi oksigen yang ada di udara dapat mencapai seluruh bagian materi yang dikomposkan. Untuk itu aerasi dari materi yang dikomposkan harus baik, dan hal tersebut bisa dicapai apabila ukuran bahan baku berkisar antara 2,5-7,5. Secara umum, sampah kota sudah memiliki ukuran tersebut. Untuk sampah kota yang memiliki ukuran terlalu besar, misalnya daun-daun yang lebar, ranting pohon, kayu dan lain-lain, perlu dilakukan pencacahan atau pengecilan ukuran terlebih dahulu.

Dengan bahan baku yang baik dan ditunjang oleh proses yang benar, maka suhu dari materi sampah yang dikomposkan akan naik hingga sekitar $70^{\circ} \mathrm{C}$. Begitu pula dengan $\mathrm{pH}$ akan berada pada rentang $\mathrm{pH}$ netral (7). Kalau itu yang terjadi, maka proses komposting dapat dikatakan berjalan baik

Proses komposting merupakan proses dekomposisi secara biologis oleh konsorsium mikroorganisme. Oleh karena itu konsorsium mikroba merupakan mesin utama dalam proses dekomposisi, sehingga keberadaannya mutlak diperlukan. Keberadaan konsorsium mikroba dalam sampah kota sudah berlimpah dan tidak perlu dirisaukan lagi ${ }^{10)}$. Untuk itu penambahan mikroba khusus dari luar menjadi tidak diperlukan.

Berdasarkan hal tersebut di atas terlihat bahwa faktor-faktor utama yang harus dipenuhi untuk suatu proses pengomposan yang baik, sudah dapat dipenuhi oleh 
sifat dan karakter sampah kota. Dengan demikian dapat dikatakan bahwa sampah kota merupakan bahan baku yang cukup baik untuk dijadikan kompos.

\section{POTENSIPUPUKORGANIKKOMPOS BERBAHAN BAKU SAMPAH KOTA}

Kompos merupakan hasil dekomposisi dari materi organik, sehingga hanya materi organik yang dapat dikomposkan. Salah satu karakteristik yang tidak menguntungkan dari sampah kota di Indonesia adalah masih tercampurnya materi organik dengan materi anorganik. Untuk itu, proses pengomposannya memerlukan upaya pemilahan terlebih dahulu, sehingga dibutuhkan biaya dan tenaga kerja tambahan.

Walaupun belum dipilah, sampah kota memiliki prospek untuk dijadikan kompos karena prosentase bahan organiknya, atau materi yang dapat dikomposkan cukup tinggi. Hasil survai menyimpulkan bahwa prosentase materi tersebut sebesar $70 \%{ }^{13)}$.

Jumlah timbulan sampah di Indonesia memiliki tendensi meningkat sejalan dengan pertambahan penduduk. Pada tahun 2009 penduduk Indonesia mencapai 231 juta jiwa $\left.{ }^{14)}\right)$. Kalau diasumsikan rata-rata timbulan sampah sebesar 2,9 liter per orang per hari ${ }^{12)}$, maka per harinya di seluruh Indonesia akan dihasilkan sampah sebesar $669.900 \mathrm{~m}^{3}$. Dari jumlah tersebut $70 \%$ dapat dikomposkan, yang berarti sejumlah $468.930 \mathrm{~m}^{3}$ berupa sampah organik. Dengan demikian prediksi produk kompos yang dapat dihasilkan sebesar $117.232,5 \mathrm{~m}^{3}$ per hari $(25 \%$ dari sampah organik), yang ekivalen dengan $58.616,25$ ton (berat jenis kompos 0,5).

Kandungan N, P dan $\mathrm{K}$ rata-rata kompos sampah kota dari 3 (tiga) kota yakni Jakarta $^{15)}$, Probolinggo ${ }^{16)}$ dan Singaraja ${ }^{17)}$ adalah: $1,27 \% \mathrm{~N}, 0,46 \% \mathrm{P}$ dan $1,27 \%$ $\mathrm{K}$. Dengan demikian kalau setiap harinya terdapat $58.616,25$ ton kompos sampah kota, hal tersebut berarti setiap harinya terdapat 744,426 ton $\mathrm{N}, 269,634$ ton $\mathrm{P}$ dan 744,426 ton $K$, yang setara dengan
$1.618,317$ ton urea $46 \% \mathrm{~N}, 748,983$ ton SP 36 dan $1.240,71$ ton $\mathrm{KCl} 60 \% \mathrm{~K}$.

Melihat komposisi unsur hara N,P dan K tersebut di atas, terlihat adanya kekurangan unsur $\mathrm{P}$ agar terbentuk komposisi pupuk $N, P, K$ yang berimbang. Kekurangan unsur $P$ tersebut dapat dipenuhi dengan penambahan pupuk fosfat alam. Dengan demikian kalau pupuk kompos dianggap sebagai suplemen dari pupuk kimia, dengan dosis rekomendasi penggunaan 2 ton per hektar ${ }^{3}$, maka luas areal sawah yang dapat dipupuk dengan kompos dari sampah, seluas 29.308 hektar. Angka tersebut memberi arti bahwa, sampah kota cukup berpotensi dalam memberikan sumbangan pada pemenuhan kebutuhan pupuk organik.

Dengan memanfaatkan sampah menjadi kompos, manfaat lain yang bisa diperoleh adalah membantu upaya pengelolaan sampah kota. Permasalahan sampah kota merupakan permasalahan yang tak habis-habisnya dihadapi oleh kota-kota di Indonesia. Kalau potensi 70\% sampah yang bisa dikomposkan dapat direalisasikan, maka jumlah sampah yang dibuang ke TPA (Tempat Pengolahan Akhir, sebelumnya Tempat Pembuangan Akhir) menjadi lebih sedikit. Permasalahan sampah yang selama ini begitu kompleks, menjadi lebih ringan.

\section{UPAYA PENGEMBANGAN PUPUK ORGANIK}

Menyadari pentingnya penggunaan pupuk organik dalam rangka untuk merehabilitasi kerusakan sumberdaya lahan, maka perlu upaya bersama dari berbagai stakeholders terkait, dengan Pemerintah sebagai inisiator utama. Untuk itulah Pemerintah cq. Kementerian Pertanian $\mathrm{RI}$, mengeluarkan berbagai kebijakan untuk mendorong penggunaan pupuk organik seperti1):

- Program Go Organik 2010 untuk tanaman pangan yang mensyaratkan penggunaan bahan organik untuk 
sarana yang dipakai, khususnya penggunaan pupuk organik.

- $\quad$ Sosialisasi penggunaan pupuk organik.

- Bantuan langsung pupuk organik dalam bentuk pupuk organik granul (POG) dan pupuk organik cair (POC).

- Bantuan alat pembuat pupuk organik dan rumah percontohan pembuatan pupuk organik.

- $\quad$ Subsidi pupuk organik dalam bentuk POG.

Kebijakan tersebut di atas ditindak lanjuti dengan program bantuan alat pembuat pupuk organik sebanyak 1.345 unit, rumah percontohan pembuatan pupuk organik sebanyak 171 unit, alokasi pupuk organik bersubsidi sebanyak 0,45 juta ton untuk tahun 2009 dan sebanyak 0,91 ton untuk tahun 2010, serta bantuan langsung pupuk organik untuk tahun 2010 sebanyak 293.293.800 kg pupuk organik granul dan 1.955.292 liter pupuk organik cair ${ }^{1}$.

Dampak positif dari kebijakan tersebut adalah bermunculannya produsen pupuk organik granul maupun pupuk organik cair, yang produknya juga menjadi marak digunakan oleh petani. Sebagai panduan kualitas pupuk organic, telah dikeluarkan Peraturan Menteri Pertanian Nomor: 70/ Permentan/SR.140/10/2011, sebagai pengganti Permentan Nomor: 28/Permentan/ SR.130/5/2009 tentang pupuk organik, pupuk hayati dan pembenah tanah. Sebelumnya telah ada Standar Nasional Indonesia yaitu SNI 19-7030-2004 tentang spesifikasi kompos dari sampah organik domestik ${ }^{18)}$. Namun demikian, adanya peraturan itu saja sebenarnya belum cukup. Yang lebih penting adalah adanya arahan, bimbingan dan pengawasan dari Pemerintah, dalam hal ini Kementerian Pertanian dan instansi terkait lainnya.

Pengomposan merupakan suatu proses dekomposisi (penguraian) berbagai materi organik yang kompleks seperti sampah, dedaunan, rumput, sisa makanan, kotoran ternak, dan serbuk gergaji. Proses penguraian menjadi bentuk yang lebih sederhana dilakukan secara biologis oleh konsorsium mikroorganisme seperti bakteri, fungi, dan aktinomicetes. Prosesnya sendiri berlangsung dalam kondisi aerobik dan termofilik yang terkendali, sehingga dihasilkan materi yang sederhana dan relatif stabil yang disebut kompos. Dengan proses pengomposan tingkat kematangan dan kandungan unsur hara dapat dikontrol, lebih mudah dan cepat diserap tanaman, serta tidak menimbulkan efek negatif terhadap pertumbuhan tanaman itu sendiri. Dengan demikian, harapan untuk meningkatkan kualitas dan produktivitas tanah dan tanaman, akan menjadi lebih mudah tercapai apabila produksi POG dibuat dari bahan organik yang telah diproses menjadi kompos terlebih dahulu ${ }^{19}$.

Dengan bahan baku berupa kompos, selain diperoleh POG yang berkualitas, manfaat proses pengomposan yang lain adalah dapat memanfaatkan bahan baku yang berasal dari seluruh potensi bahan organik yang ada, dan tidak tergantung pada satu atau beberapa bahan organik saja. Hal ini menjadi penting karena tingginya potensi bahan organik yang dapat dijadikan kompos sebagai bahan baku POG, termasuk sampah organik.

Namun kecenderungan produsen POG hanya menggunakan bahan baku tertentu saja ${ }^{20)}$, yaitu bahan organik yang sudah terdekomposisi secara alamiah dengan ciri sudah lapuk,halus dan kering, dan jarang menggunakan bahan organik yang secara khusus diproses menjadi kompos terlebih dahulu. Dengan proses dekomposisi secara alamiah, maka prosesnya menjadi sulit dikontrol, selain bahan bakunya menjadi terbatas. Bahan organik yang favorit untuk digunakan adalah blotong (limbah pabrik gula) dan kotoran hewan (kohe), terutama kotoran sapi dan kotoran ayam.

Penggunaan kotoran hewan dilatarbelakangi oleh kebiasaan petani yang selama ini telah menggunakan kotoran hewan sebagai pupuk kandang dan 
dianggap sebagai pupuk yang baik untuk meningkatkan hasil produksi pertaniannya.

Namun seperti yang telah dibahas dalam bab sebelumnya, pupuk organik kompos tidak hanya berbahan baku kotoran hewan. Semua bahan organik, yaitu semua bahan yang berasal dari makhluk hidup, apakah itu manusia, hewan atau tumbuhan merupakan bahan baku yang dapat dijadikan kompos. Semakin beragam bahan baku yang digunakan, semakin mudah membentuk kondisi optimal dari parameter-parameter yang dibutuhkan untuk suatu proses komposting yang baik.

Mengingat kebutuhan pupuk organik yang tinggi yaitu 4,67 juta ton untuk tahun 2009 dan 4,14 juta ton untuk tahun 20101), maka seharusnya bahan baku pupuk organik kompos bisa memanfaatkan semua potensi bahan organik yang ada, termasuk sampah kota.

Untuk menggunakan sampah kota, terlihat seolah ada keengganan. Ada anggapan bahwa kompos sampah kota memiliki kualitas yang tidak baik. Baik tidaknya produk kompos yang dihasilkan tergantung dari bahan baku dan proses pembuatan komposnya. Sampah kota merupakan salah satu bahan baku kompos yang baik. Oleh karena itu kalau proses pengomposan sampah kota berjalan baik, maka produk kompos yang dihasilkan juga baik. Hasil kajian terhadap kompos sampah kota yang telah dilakukan di Jakarta $^{15)}$, Probolinggo ${ }^{16)}$ dan Singaraja ${ }^{17)}$, membuktikan bawa kompos yang dibuat dari sampah kota berkualitas baik.

Kompos sebagai pupuk organik bukanlah untuk menggantikan pupuk kimia yang sudah lebih dikenal oleh para petani. Pupuk organik adalah pelengkap bagi pupuk kimia dan sebaliknya. Pupuk organik dan pupuk kimia akan lebih optimal dan lebih efisien penggunaannya bila dimanfaatkan secara bersama-sama.

Kompos/pupuk organik yang mengandung unsur hara makro dan mikro lengkap tetapi dalam jumlah sedikit, akan dicukupi kekurangan jumlahnya oleh pupuk kimia yang memiliki kandungan hara yang tinggi, walaupun keberagamannya terbatas pada unsur N, P, K, Ca dan Mg saja. Pupuk organik dapat memperbaiki sifat fisik, biologi dan kimia tanah yang biasanya rusak karena akibat penggunaan pupuk kimia yang tidak bijaksana.

Keberhasilan program penggunaan pupuk organik yang salah satunya adalah kompos, sangat tergantung kepada keyakinan petani bahwa menggunakan pupuk organik memang lebih baik. Kenyataan yang ada adalah upaya untuk memasyarakatkan pupuk organik kepada petani bukanlah hal yang mudah, karena harus merubah kebiasaan petani yang selama ini telah biasa menggunakan pupuk kimia dan sedikit sekali menggunakan pupuk organik. Kepercayaan petani untuk menggunakan pupuk organik harus ditumbuhkan. Kepercayaan tersebut yang saat ini mulai tumbuh harus dijaga dengan baik, yaitu dengan upaya penyediaan pupuk organik yang berkualitas baik, apakah dalam bentuk pupuk kompos ataupun pupuk organik yang lain.

\section{KESIMPULAN}

Berdasarkan materi yang telah disampaikan, dapat ditarik beberapa kesimpulan sebagai berikut:

1. Penurunan kualitas dan produktivitas sumberdaya lahan pertanian, terutama disebabkan oleh rendahnya kandungan C-organik dan pemupukan yang tidak diimbangi dengan pupuk organik. Cara mengatasinya adalah mengembalikan bahan organik ke lahan pertanian melalui penggunaan pupuk kompos atau POG berbahan baku kompos.

2. Pupuk kompos sebaiknya dibuat dari seluruh potensi bahan organik yang ada, termasuk sampah kota. Timbulan atau produksi sampah kota yang besar dengan prosentase bahan organik yang tinggi, memiliki karakteristik yang 
cocok untuk dijadikan pupuk kompos berkualitas.

3. Keberhasilan program penggunaan pupuk kompos dan pupuk organik yang lain sangat bergantung kepada dukungan seluruh stakeholders terkait, serta kepercayaan dan keyakinan petani akan pupuk organik. Untuk itu produk pupuk organik harus berkualitas baik dan mutu tersebut tetap dapat dipertahankan.

4. Dengan ketersedian pupuk kompos atau pupuk organik lain yang berkualitas, dan diberikan secara berimbang bersama pupuk kimia, maka kualitas dan produksivitas sumberdaya lahan pertanian dapat ditingkatkan sehingga dapat mendukung dan memperkuat kemandirian pangan.

\section{DAFTAR PUSTAKA}

1. Direktorat Jenderal Tanaman Pangan, 2010. Pelaksanaan PSO Subsidi Benih dan Pupuk Tahun Anggaran 2010, Kementerian Pertanian, Jakarta.

2. Iswandi, A., 2010. Peranan Pupuk Organik dan Pupuk Hayati dalam Peningkatan Produktivitas Beras Berkelanjutan. Makalah pada Seminar Nasional Peranan Pupuk NPK dan Organik dalam Meningkatkan Produksi dan Swasembada Beras Berkelanjutan. Balai Besar Litbang Sumberdaya Lahan Pertanian, Badan Penelitian dan Pengembangan Pertanian, Kementerian Pertanian, Jakarta.

3. Las, I., 2010. Arah dan Strategi Pengembangan Pupuk Majemuk NPK dan Pupuk Organik, Seminar Nasional Peranan Pupuk NPK dan Organik dalam Meningkatkan Produksi dan Swasembada Beras Berkelanjutan, Badan Penelitian dan Pengembangan Pertanian, Kementerian Pertanian, Jakarta.
4. Kementerian Pertanian Republik Indonesia, 2010. Pemulihan Kesuburan Tanah pada Lahan Sawah Berkelanjutan. Badan Litbang Pertanian dan Ditjen Tanaman Pangan, Jakarta.

5. Munawar, A., 2011. Kesuburan Tanah dan Nutrisi Tanaman, IPB Press, Bogor.

6. Kementerian Pertanian Republik Indonesia, 2010. Go Organik 2010

7. Haug, R.T., 1980. Compost Engineering, Principles and Practice, An Arbor Science Publisher Inc., Michigan.

8. Tchobanouglous, G., H. Theisen and S. Vigil, 1993. Integrated Solid Waste Management, Engineering Principles and Management Issues. Mc Graw-Hill Inc., USA.

9. Epstein, E., 1997. The Science of Composting, Technomic Publishing Company Inc., USA.

10. Wahyono, S., F.L. Sahwan dan F. Suryanto, 2003. Menyulap Sampah Menjadi Kompos, Pusat Pengkajian dan Penerapan Teknologi Lingkungan, BPPT, Jakarta.

11. Menteri Pertanian Republik Indonesia, 2011. Peraturan Menteri Pertanian No 70/Permentan/SR.140/10/2011, Tentang Pupuk Organik, Pupuk Hayati dan Pembenah Tanah. Berita Negara Republik Indonesia Tahun 2009 Nomor 137.

12. Dinas Kebersihan DKI Jakarta, 2005. Laporan Akhir Solid Waste Management for DKI Jakarta, Master Plant Review and Program Development WJEMP Loan 4612-INO/Credit 3519-IND (DKI 3-11). 
13. Kementerian Negara Lingkungan Hidup, 2008. Statistik Persampahan Indonesia Tahun 2008.

14. Badan Pusat Statistik, 2010. Penduduk Indonesia 2009.

15. Sahwan, F.L., 2010. Kualitas Produk Kompos dan Karakteristik Proses Pengomposan Sampah Kota Tanpa Pemilahan Awal. Jurnal Teknologi Lingkungan Pusat Teknologi Lingkungan-BPPT, 11(1):79-85

16. Pusat Teknologi Lingkungan, 2008. Laporan Kegiatan Pemanfaatan Sampah Kota Menjadi Pupuk Organik dengan Teknologi Accelerated Revolver Windrow Composting untuk Ketahanan Pertanian Padi di Probolinggo, BPPT, Jakarta.

17. Sahwan, F.L., S. Wahyono dan F. Suryanto, 2010. Kualitas dan Produksi Pupuk Organik Granul (POG)
Sampah Kota Serta Manfaatnya Untuk Mengurangi Pengaruh Emisi Gas Rumah Kaca. Jurnal Teknologi Lingkungan, Pusat Teknologi Lingkungan-BPPT, Edisi Khusus Global Warming: 51-59.

18. Badan Standarisasi Nasional, 2004. Standar Nasional Indonesia, SNI 197030-2004, Spesifikasi Kompos dari Sampah Organik Domestik.

19. Wahyono, S., F.L. Sahwan dan F. Suryanto, 2011. Membuat Pupuk Organik Granul dari Aneka Limbah. PT Agro Media Pustaka, Jakarta.

20. Sahwan, F.L., S. Wahyono dan F. Suryanto, 2011. Evaluasi Proses Produksi Pupuk Organik Granul (POG) yang Diperkaya dengan Mikroba Fungsional. Jurnal Teknologi Lingkungan, Pusat Teknologi Lingkungan-BPPT, 12 (1):7-16. 